\title{
RAPD PROFILE OF WINGED-BEAN [Psophocarpus tetragonolobus (L.) DC] MUTATED USING ETHYL-METHANE SULPHONATE
}

\author{
Fajri Hartanti ${ }^{* *}$, Adi Amurwanto ${ }^{2)}$, Agus H. Susanto ${ }^{2)}$ \\ 1)Plant Biology Mayor of Bogor Agricultural University, Bogor, Indonesia. \\ ${ }^{2)}$ Biology Faculty of Jenderal Soedirman University, Purwokerto, Indonesia. \\ *email: fajrihartanti@yahoo.com
}

\begin{abstract}
Genetic diversity of winged-bean [Psophocarpus tetragonolobus (L.) DC] can be produced by induced mutation with EMS (ethyl-methane sulphonate). To identify the genetic diversity after EMS application on winged-bean, molecular analysis using RAPD (Randomly Amplified Polymorphic DNA) technique was carried out. This study aims to identify RAPD profile of wingedbean after EMS application. Winged-bean seeds of both long and short pod types were soaked in wet paper towels for 6 hours followed by soaking in EMS of $0.3 \%$ and $0.5 \%$ for 4 hours. Wingedbean seeds of both pod types without EMS served as control. Ten of the 30 primers operon technologies USA and 2 primers bangalore genei showed sufficiently clear bands (OPA 1, OPA 3 , OPA 10, OPA 15, OPA 19, OPB 1, OPB 6, OPB 7, ES10C27, and ES10C28). All the ten primers produced polymorphic fragments with a total number of 320 and size ranging from $100 \mathrm{bp}$ to 2,000 bp. As many as 66 loci were observed. The polymorphism values obtained ranged from $16.67 \%$ to $46.97 \%$. This low polymorphism values indicate that EMS concentrations applied have not resulted in sufficiently high genetic variation. At the same time, the genetic distance observed were only 0.11 to 0.41 .
\end{abstract}

Keywords: winged-bean, EMS, RAPD, genetic diversity

\section{Introduction}

Winged-bean is tropical vegetable crop commonly found in Indonesia. It has several potentials that almost all of its parts can be used as vegetable (Krisnawati, 2010) with sufficiently high nutrition contents (Bostid, 1981). Moreover, it could also be as an alternative source of energy (Rismunandar, 1983), erotion control in dry land, nitrogen fixation, and stabilizing poor soil (Bostid, 1981; Kisnawati, 2010). Although there are so many potentials of

\section{Materials and Methods}

Plant material

Winged-bean seeds of both long and short pod types were soaked in wet paper towels for 6 hours followed by soaking in EMS of $0.3 \%$ and $0.5 \%$ for 4 hours. Winged-bean seeds of both pod types without EMS served as control.

\section{DNA extraction}

Genomic DNAs were isolated from leaves following CTAB protocol (Doyle and Doyle, 1990). DNA quality was estimated by electrophoresis in agarose winged-bean, no serious effort has been made to increase its productivity.

In Indonesia, the low productivity of winged-bean is related to its low genetic variation (Haryoto, 1995; Krisnawati, 2010). Genetic improvement by means of mutation can be used to produce genetic variation (Snutsad and Simon, 2010). Various mutagen effect can be detected by using RAPD technique. Here we are presenting RAPD profile of winged-bean after mutation with EMS (ethyl-methane sulphonate).

gel, while DNA quantity was measured using spectrophotometer.

DNA Amplification

Eight random primers from Operon Technologies and 2 primers from bangalore genei was tested for their ability to amplify scorable and reproducible DNA fragment. PCR reaction were carried out in $10 \mu \mathrm{L}$ reaction mix containing $5 \mu \mathrm{L}$ go taq green PCR master mix 2X; 2,25 $\mu \mathrm{L}$ DNA; 0,25 $\mu \mathrm{L}$ primer, and 2,5 $\mu \mathrm{L}$ water nuclease free. Amplification was performed in PCR Thermal Cycler BOECO, programmed for 
45 cycles of each of the following; $94^{\circ} \mathrm{C}$ for $1 \mathrm{~min}, 37^{\circ} \mathrm{C}$ for $1 \mathrm{~min}, 72^{\circ} \mathrm{C}$ for $1 \mathrm{~min}$ $30 \mathrm{sec}$. A final elongation step of $5 \mathrm{~min}$ at $72^{\circ} \mathrm{C}$ was included (Malviya and Yadav, 2010 with a little modification)

\section{Result and Discussion}

All the ten primers produced RAPD fragments and individual primer showed the same intensity for all samples (Figure 1). All the ten primers produced polymorphic fragments with a total

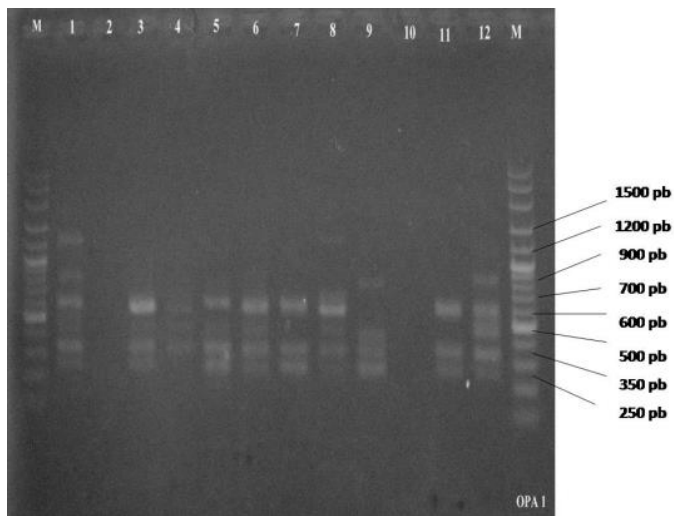

a

\section{Data Analisys}

DNA fragments from the amplifications products were transformed into binary data and were analysed using Gene Alex programme version 6.1.

number of 320 (Table 1) and sizes ranging from $100 \mathrm{bp}$ to $2,000 \mathrm{bp}$. As many as 66 loci were observed. The difference of fragment pattern showed polymorphism (Poerba and Martanti, 2008).

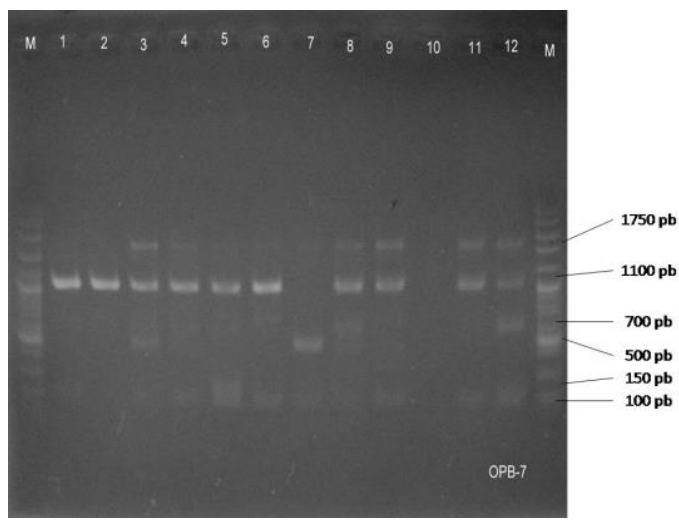

b

Figure 1. Electrophoretic analysis of amplification products using primers a) OPA 1 and b) OPB 7

1 and 2. PDN, 3 and 4.PD 0,3\%, 5 and 6. PD 0,5\%, 7 and 8. PJN, 9 and 10.PJ 0,3\%, 11 and 12. PJ 0,5\%

$\mathrm{PD} \mathrm{N}=$ control short pod

PD $0,3 \%=$ short pod soaked by EMS $0,3 \%$

PD $0,5 \%=$ short pod soaked by EMS $0,5 \%$

$\mathrm{PJ} N=$ control long pod

PJ $0,3 \%=$ long pod soaked by EMS $0,3 \%$

PJ $0,5 \%=$ long pod soaked by EMS $0,5 \%$

Table 1. Primers and number of fragments

\begin{tabular}{ccc}
\hline no. & primers & $\begin{array}{c}\text { number of } \\
\text { fragments }\end{array}$ \\
\hline 1 & OPA-1 & 41 \\
2 & OPA-3 & 40 \\
3 & OPA-10 & 43 \\
4 & OPA-15 & 15 \\
5 & OPA-19 & 19 \\
6 & OPB-1 & 21 \\
7 & OPB-6 & 33 \\
8 & OPB-7 & 36 \\
9 & ES1C027 & 35 \\
10 & ES1C028 & 37 \\
\hline & Total & 320 \\
\hline
\end{tabular}

Based on these results the value of genetic distance in six winged-bean populations was in the range of 0.11 to
0.41 . The highest value of genetic distance of 0.41 was found between long pods with EMS $0.3 \%$ and long pods with EMS $0.5 \%$, while the lowest value of 0.11 was observed between two samples of short pods witrh EMS $0.5 \%$.

Table 2. Percentage of polymorphism loci in six populations

\begin{tabular}{ll}
\hline Population & \%Polymorpism \\
\hline PD N & $22,73 \%$ \\
PD 0,3\% & $34,85 \%$ \\
PD 0,5\% & $16,67 \%$ \\
PJ N & $46,97 \%$ \\
PJ 0,3\% & $37,88 \%$ \\
PJ 0,5\% & $46,97 \%$ \\
\hline \multicolumn{2}{c}{ Based on the polymorphism }
\end{tabular}
percentages obtained, it can be said that there is no correlation between polymorphism and level of EMS treatment 
or pod type (Table 2). This is indicated by the values of polymorphisms which are inconsistent among treatments. The absence correlation indicates that mutation is random in nature (Snustad and Simons, 2010).

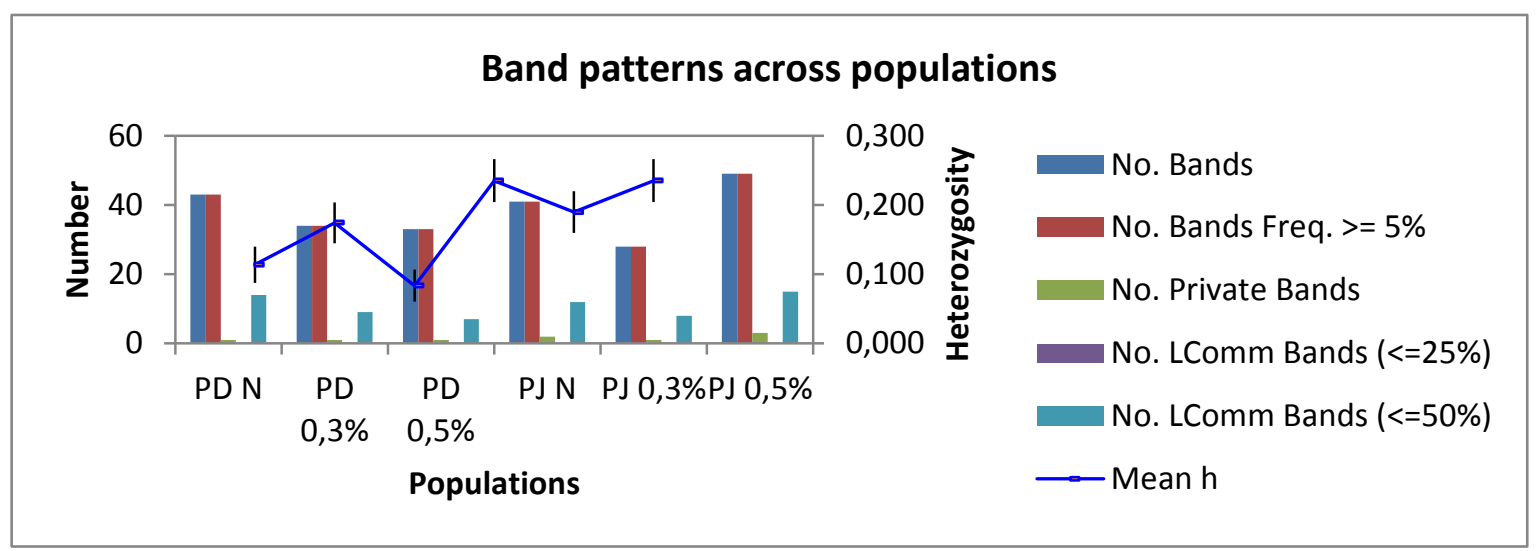

Figure 2. Histogram of heterozygosity in each winged-bean population

An increase in the number of fragments is in line with the increase in heterozygosity value (Figure 2). Heterozygosity values generated by the short- pods are relatively stable, both in normal and mutant types, whereas there is a tendency of difference between normal and mutant types in long pods.

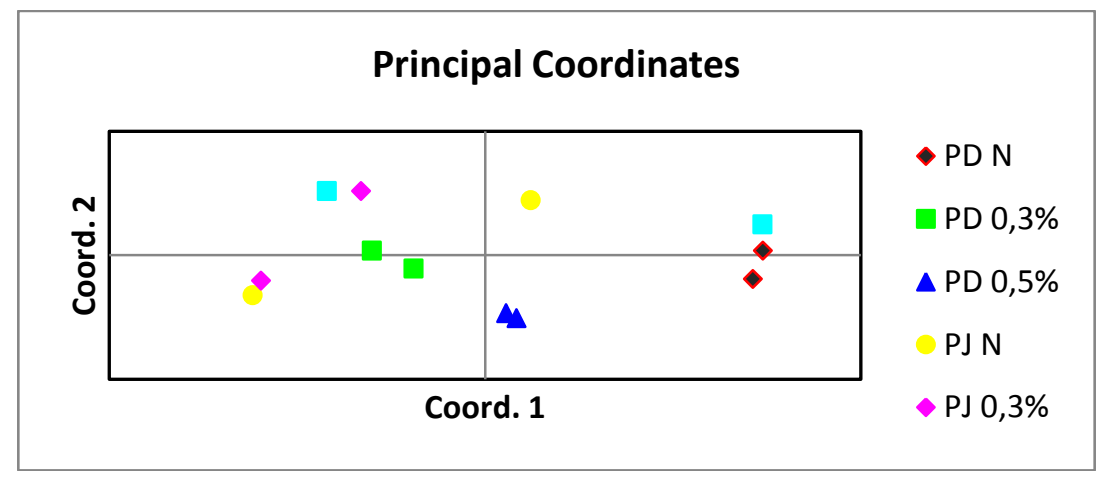

Figure 3. PCA of winged- bean populations

PCA analysis shown in Figure 3 reveals that short pods with EMS $0.5 \%$ have a close kinship with those with EMS $0.3 \%$,

\section{Conclusion}

RAPD profile of winged-bean mutated with EMS showed genetic variation either within or between populations of both pod types.

\section{References}

Bostid. 1981. The Winged Bean A HighProtein Crop for the Tropic second while normal long pods are close to those with EMS $0.3 \%$ and slightly distant with those with EMS 0.5\%.

\section{Acknowledgement}

The authors wish to thank Unsoed DIPA grant research project 2011 for financial support provided.

edition. National Academy Press; Washington, D.C. 
Doyle, J.J. and Doyle, J.L. 1990. Isolation of plant DNA from fresh tissues. Focus 12: 13 - 15.

Haryoto. 1995. Tempe dan Kecap Kecipir. Kanisius; Yogyakarta.

Krisnawati, A. 2010. Keragaman genetik dan potensi pengembangan kecipir (Psophocarpus tetragonolobus L.) di Indonesia. Jurnal Litbang Pertanian 29(3): 113 - 119.

Poerba, Y.S. dan Martanti, D. 2008. Keragaman genetik berdasarkan marka random amplified polymorphic DNA Amorphophallus muelleri Blume di Jawa. Biodiversitas 9(4) : $245-249$.

Rismunandar, 1983. Kecipir Penghasil Protein dan Karbohydrat yang Serbaguna. Sinar Baru; Bandung.

Snustad, D. P. and Simons, M. J. 2010. Principles of Genetics fifth edition. John Wiley, Inc. 